\title{
Taking Historical Fundamentalism Seriously
}

Johann N. Neem

Western Washington University, johann.neem@wwu.edu

Follow this and additional works at: https://cedar.wwu.edu/history_facpubs

Part of the History Commons

\section{Recommended Citation}

Neem, Johann N., "Taking Historical Fundamentalism Seriously" (2011). History Faculty and Staff Publications. 53.

https://cedar.wwu.edu/history_facpubs/53

This Article is brought to you for free and open access by the History at Western CEDAR. It has been accepted for inclusion in History Faculty and Staff Publications by an authorized administrator of Western CEDAR. For more information, please contact westerncedar@wwu.edu. 


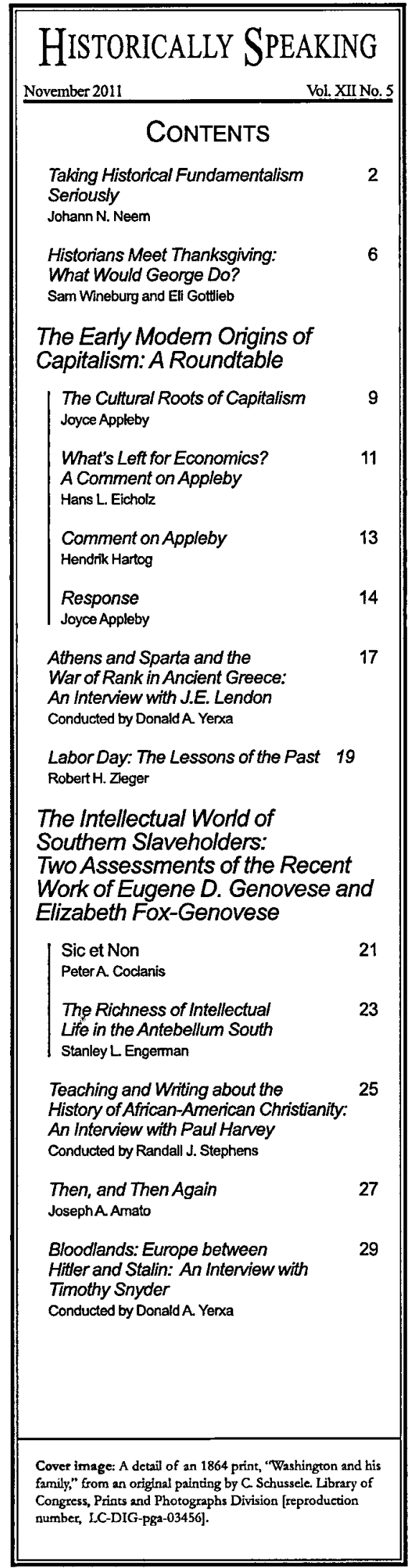

\title{
TAKING HISTORICAL Fundamentalism Seriously
}

\author{
Johann N. Neem
}

I $\mathrm{n}$ her tecent book The Wbites of Their Eyes Jill Lepore argues that today's conservatives' embrace of the founding is not just another example of citizens using the Revolution for political purposes - which generations of Americans have done-but instead an attack on the very idea of history. Tea Partiers, she concludes, practice a form of "antihistory."

"In anthistory," Lepore writes, "time is an illusion. Either we're there, two hundred years ago, or they'te here, among us."' Tó Tea Partiers, there is no distance between the past and present; the past is not a foreign country. To believe that the founders can speak to us directly, not mediated by the mists of time, "is to subscribe to a set of assumptions about the relationship between the past and the present stricter, even, than the strictest form of constitutional originalism." It is to be, Lepore argues, a historical "fundamentalist."?

Lepore rightly finds the Tea Party approach to history quite troubling. As her book makes clear, the founders lived in a time and place very different from ours. It was a time of slavery; when women lacked political equality; and when one needed property to vote. Moreover, American democracy has always been a work in progress; struggles from below as well as from above matter. We do not want to treat a few founding fathers as gatekeepers to the true America.

Lepore dismisses the Tea Partiers' effort to find wisdom in the founders: "What would the founders do?' is, from the point of view of historical analysis, an ill-considered and unanswerable question, and pointless, too." To seek guidance from men who lived over 200 years ago is "not history. It's not civil religion, the faith in democracy that binds Americans together. It's not originalism or even constitutionalism. That's fundamentalism."

While it is certainly open to debate whether we Americans today should seek guidance from men and women who lived over two centuries ago, Lepore's tone is dismissive and, at times, derisive of the effort of many Americans to learn from the past. It's the same tone candidate Barack Obama expressed when he referred to ordinary Americans who "cling to guns or religion or antipathy to people who aren't like them or anti-immigrant sentiment or anti-trade sentiment as a way to explain their frustrations" and that Thomas Frank uses when he wonders "what's wrong with Kansas?", As scholars, however, we need to take historical fundamentalism seriously. In fact, we cannot afford to dismiss it condescendingly. Lepore is right about the American Right's rejection of professional his- 
treats human nature as changing over time-is only one variety of historical consciousness, and one that rests on recent assumptions.

Professional historians have themselves reached similar conclusions. As new theories of knowledge have undermined the faith we historians once had in our method, the possibility exists for professional history to return to history's moral roots, and be once again a conversation with the present: Others have suggested that we should see historical writing as an aesthetic or literary, zather than scientific, enterprise: We may choose not to go down this path, believing, for good reasons, that academic history's primary purpose is to understand the past to the best of our ability, which requires using appropriate methods and, yes, a commitment to context.

However we proceed, we need to find a way to speak to the broader public, to the people who read David Barton. Barton is one of America's most popular history writers, and he is most famous for his argument that today's scholars have misconstrued the role of religion during the founding era. To Barton, scholars committed to the absolute separation of church and state have read their politics back into the past. In response, Barton argues that the founders were not only more religious but much more committed to the public role of religion than either today's Supreme Court would allow or most scholars would admit.

Lepore sees in historical fundamentalism a Counter-Reformation, but Barton and others would see themselves in the spirit of the Reformation. Barton might be considered professional history's Martin Luther. On his website wwwwwallbuilders.com-the 21st-century equivalent of the Wittenburg church doot-Barton offers interested readers access to the founders' original words." Like Luther, Barton seeks to slice through the layers of dogma that he associates with professional history. Unlike most of us, he does not want his experience with the past to be mediated by historiography. He urges his followers to read the founders for themselves rather than allow professional historians to serve as history's priests. By clicking on the "Library" link one can go directly to documents in which various founding fathers speak about the religious foundations of the American republic.

Barton's public statements have at times been outrageous, and he no doubt gets much wrong, but so do academics. For example, in their book The Godless Constitution Isaac Kramnick and R. Laurence Moore argue that the U.S. Constitution is " 2 godless document." They rightly note what many commentators at the time recognized. Not only is
God not tecognized by the Constitution, but the framers ensured that "no religious Test shall ever be required as a Qualification to any Office or public Trust under the United States." Despite Kramnick and Moore's admission that their book is a "polemic" and that they "recognize that religion is important in America life," the book's narrative is a one-sided attack on religion in public life. Responding to Richard John Neuhaus's worry-one shared by many founders, most notably John Adams and Benjamin Rush-- that without a transcendent point of reference, morality will founder, the authors reply, "with all due respect, that is nonsense." Although offering more due respect to sociologist Robert Bellah, they dismiss what Bellah calls America"s "civil religion" as nothing more than a tool "to stir a sense of national arrogance."

Such an approach dismisses the thoughtfulness and intelligence of those with whom we disagree and undermines our ability to speak with those whose minds we wish to change. More important, Kramnick and Moore downplay the distance between the past and present by referring to "secularism as a fundamental principle of American government." By ignoring context and asking the founders to speak directly to present aspirations, Kramnick and Moore offer a good example of Lepore's historical fundamentalism.

In response, Barton asks his readers to turn away from historians and back to the founders themselves. In fact, he contextualizes the First Amendment quite effectively in his equally polemical book, Separation of Church and State. In this short book Barton reminds readers that the First Amendment was never intended to establish a godless nation. Instead, Barton concludes, the founders proclaimed over and over that the new republic's success depended on morality, and that morality would be derived from religion. To Barton, "not only did the Founders never intend that the First Amendment be a vehicle to separate religious principles from public affairs but they believed that through its Free Exercise clause they had protected these principles and kept them in the public square."'

The disagreements between Kramnick and Moore and Barton show us how difficult it is to determine the appropriate context to understand the past. On the one hand, Kramnick and Moore are no doubt right that the Constitution did not establish a Christian state. Instead, it explicitly separated religion from formal political structures. Building on his Virginia expetience, James Madison designed in the First Amendment a wall between church and state much higher than that in many Revolutionary-era state constitutions." On

\begin{tabular}{|c|c|}
\hline \multicolumn{2}{|c|}{$\begin{array}{l}\text { Historically Speaking } \\
\text { The Bulletin of the Historical Society } \\
\text { Published by The Johns Hopkins University Press }\end{array}$} \\
\hline \multicolumn{2}{|c|}{$\begin{array}{ll}\text { Senior Editors: } & \text { Joseph S. Lucas and } \\
\text { Donald A. Yerxa } \\
\text { Editor \& Designer: Randall J. Stephens }\end{array}$} \\
\hline \multicolumn{2}{|c|}{ 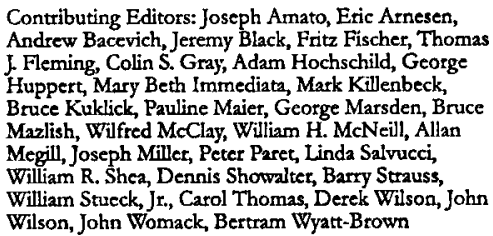 } \\
\hline \multicolumn{2}{|c|}{ 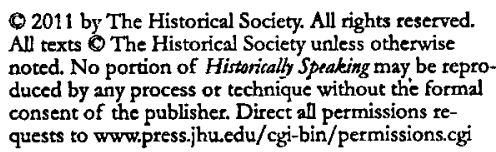 } \\
\hline \multicolumn{2}{|c|}{$\begin{array}{l}\text { Historically, Speaking (ISSN 1941-4188) is published five } \\
\text { times a year for The Historical Society by The Johns } \\
\text { Hopkins University Press, } 2715 \mathrm{~N} \text {. Chatles Street, Balti- } \\
\text { more, MD 21218-4363 }\end{array}$} \\
\hline \multicolumn{2}{|c|}{$\begin{array}{l}\text { Postrnaster: Send address changes to Historitally, Sprake- } \\
\text { ing, } 656 \text { Beacon SL, Mezzanine, Boston, MA } 02215\end{array}$} \\
\hline \multirow{2}{*}{\multicolumn{2}{|c|}{$\begin{array}{l}\text { Correspondence Please write the Editors, Historically } \\
\text { Spreaking, } 656 \text { Beacon St., Mezzanine, Boston, MA } \\
02215 \\
\text { Membership and subseriprion: Please see ad on } \\
\text { page } 26\end{array}$}} \\
\hline & \\
\hline \multicolumn{2}{|c|}{ HISTORICAI. } \\
\hline \multicolumn{2}{|c|}{ 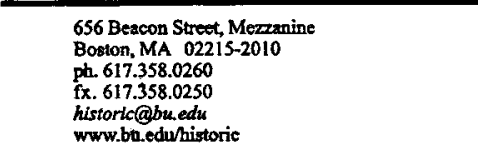 } \\
\hline \multicolumn{2}{|l|}{$\begin{array}{l}\text { PRESIDENT } \\
\text { Mark M. Smith }\end{array}$} \\
\hline \multicolumn{2}{|l|}{$\begin{array}{l}\text { DIRECTOR } \\
\text { Joseph S. Lucas }\end{array}$} \\
\hline \multicolumn{2}{|l|}{$\begin{array}{l}\text { SECRETARY/TREASURER } \\
\text { Jeffrey Vanke }\end{array}$} \\
\hline \multicolumn{2}{|c|}{$\begin{array}{l}\text { ASSISTANT DIRECTOR, MANAGING EDITOR, } \\
\text { THE JOURAL OF THE HISTORCALAL SOCIETY } \\
\text { Scott Hovey }\end{array}$} \\
\hline \multicolumn{2}{|c|}{$\begin{array}{l}\text { SENIOR EDITORS, HISTORTCALLY SPEAKING } \\
\text { Joseph S. Luccas } \\
\text { Donald A. Yerza }\end{array}$} \\
\hline \multicolumn{2}{|c|}{$\begin{array}{l}\text { EDTOR, HISTORICALLY SPEAKING } \\
\text { Randall J. Stephens }\end{array}$} \\
\hline \multicolumn{2}{|c|}{$\begin{array}{l}\text { EDTrOR, THE JOURNAL OF THE } \\
\text { HISTORICAL SOCIETY } \\
\text { Peter A. Coclanis }\end{array}$} \\
\hline $\begin{array}{l}\text { BOARD OF GOVERNORS } \\
\text { Carol Anderson } \\
\text { Eric Amesen } \\
\text { Charles Banner-Haky } \\
\text { Chris Beneke } \\
\text { Martin Burke } \\
\text { David Chispell } \\
\text { Peter Coclanis } \\
\text { Bruce Cole } \\
\text { Jennifer Dellon } \\
\text { Pamela Bdwards } \\
\text { Louis Ferleger } \\
\text { John Higgineon } \\
\text { Harriot Lightman }\end{array}$ & 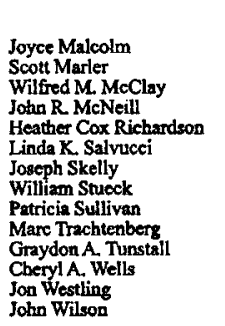 \\
\hline
\end{tabular}


the other hand, Barton is also correct that the draftsmen of the First Amendment took it for granted that Protestant values in civil society would help sustain the republic over time, that Americans would be Christian even if the state was not.

To many conservatives, the issue is more complex than Lepore's dichotomy of history and antihistory would suggest. Not only is antihistory a form of history, but we historians are sometimes guilty of practicing it. The real debate, therefore, is over authority. Barton and many other Americans are no longer willing to defer to professional historians; we are not credible. In Texas conservative politicians have taken to tewriting historical standards to correct for what they consider our biases.

But why have we so effectively lost the trust of the conservative reading public? Why are conservatives convinced that, as Lepore puts it, "the academic study of history . .. is a conspiracy and, furthermore, blasphemy"?"

One major reason is that Americans have never been willing to defer to an elite intellectual class. Intellectuals hold an ambiguous place in a society founded on the premise that, as Thomas Paine put it, every person should be able to understand "simple facts, plain arguments, and common sense" and "determine for themselves" the truth. To many Americans, intellectuals seem unnecessary. This has been the foundation for a populism in which, as Sophia Rosenfeld writes in her recent book, popular judgments "are in possession of a kind of infallible, instinctive sense of what is right and true. . . that necessarily trumps the 'expert' judgments and knowledge of a minority of establishment insiders.".":

For many conservatives, the professional, tenured historical profession is a priestly class that defies common sense. And here Americans echo not just Luther, but also Thomas Jefferson. Jefferson believed that for generations the established church had denied people açcess to Jesus's teachings. In order to sustain their own earthly power, church leaders had fabricated "Platonic mysticisms" that perverted Jesus's message. The clergy interposed themselves between Jesus and his followers. As a result, Jefferson argued for a "wall of separation" between church and state in order to undermine the established clergy's mediating role." Jesus's teachings shouid be accessible to common sense, Jefferson believed, and so should, many Americans believe, those of our founding fathers.

Many Americans consider us professional historians the equivalent of Jefferson's priestly class. They accuse of us of constructing our own "Platonic mysticisms," what Lepore calls context, but others see as dogma. Barton thus urges Americans to return to the original writings untouched by pro- fessional historiography. In many ways, wallbuilders.com is like Jefferson's cut-and-paste Bible, a purified past, stripped of what Barton considers historiography's accretions.

In Separation of Church and State Barton makes his case early when he relays a conversation he had with a congressman. The congressman, a lawyer, was certain that the phrase "separation of church and state" appears in the Constitution. When Bar-

relentless and acerbic attacks on faculty, such attacks resonate with citizens because they draw on a deep and in many ways worthy tradition." When we historians talk of context, many Americans hear Jefferson's mysticisms designed to limit their access to the true founders.

Certainly, we do not want academic history to become poptular history. The role of academic history is to ask questions even when the answers prove unpopular. Critics of the academy are often frustrated that we are accountable for the knowiedge we produce and teach rather than dircctly to the market. ${ }^{2}$ Yet, even as we defend ourselves from such critics, we must remember that we, too, can be wrong. As historians, we often condemn past elites who sought to maintain power against the legirimate aspirations of the people. But when it comes to us, we naturally have a harder time. Our starting point must be that history proves that sometimes elites are wrong and common sense is right. We must be humble since we, of all people, should know better.

Humility, then, may be what we need. Attitude matters. In a democratic culture suspicious of intellectuals, we cannot force citizens to accept our doctrines, nor do we wish to. Instead of con-

ton asked him to find it, and the congressman discovered it is not in the text of the First Amendment, he was dumbfounded. The congressman proclaimed, "I can't believe this! In law school they always taught us that's what the First Amendment said!" When asked if he had read the Constitution for himself, the congressman replied, "We were never required to read it in law schooll"' In this case, law professors- - but it might as well have been historians-interpose themselves and their dogma between the text and the citizen, much like Jefferson's priestly class had done for religion.

So what is to be done? One reason that Americans read little academic history is that most of it is not written for them. This is not a bad thing. As Gordon Wood asscrts, academic history is a different kind of enterprise from popular history. It focuses on analysis, not plot lines and characters. It is not meant to be accessible; in fact, "new and innocent readers often have to educate themselves in the historiography of the subject before they can begin to make sense of many of these monographs." But if we historians wish to be more influential, Wood argues, we must translate academic history for 2 broader audience."

Yet historical fundamentalism speaks to something deeper than the failure of academic historians to write for the public. It reflects a broader loss of faith in scholars as mediators of historical truth. While much of this distrust can be attributed to conservative politicians' and the corporate media's demning other Americans' understandings of history, we should reach out in the spirit of fellowship. Our goal is explanation, not compulsion. We hope to change minds, not offend them. Whether in the classroom, in our writing, or in the broader public sphere, we must learn to speak from within, as fellow Americans, rather than from without, as a privileged class.

This is going to be tough work, but if we don't find a way to communicate, the cost could be quite high. Sticking with the clergy example, David Hollinger has written in his recent Organization of American Historians presidential address that one of the reasons for the success of evangelicalism and fundamentalism in post-World War II America is that mainstream ecumenical Protestant ministers moved so far away from their congregants' beliefs that they were no longer trusted authorities. In short, ecumenical ministers lost the ability to speak to, and with, the Christian laity. As mainstream ministers lost their influence, evangelicals and fundamentalists claimed the right to speak for ordinary people and for America."

The same is true of professional historiansand, one might add, professional academics. We have done a bad job speaking with the public rather than against them. We have tended to be critical of an America they love without offering redemption. We have engaged in what Todd Gitlin calls the "pleasures of condemnation." we dismiss our fellow Americans' desires to forge a usable past, and 
thus we have left that work to amateurs and, too often, the corporate media. Lepore herself reflects this attitude: "The study of history requires investigation, imagination, empathy, and respect. Reverence just doesn't enter into it" "\# Except, of course, for the many Americans who revere their past and find meaning in it.

I am proud to be a professional historian, but something about the historical fundamentalists' critique haunts me; I cannot dismiss it. If we historians act like the established clergy of Jefferson's day, we will be portrayed—rightly or wrongly —as elites alienated from the lives and struggles of ordinary people. In time we may find ourselves not just disestablished but preaching a gospel that finds no followers.

Jobazn Neem is associate professor of bistory at Western Wasbington University. He is the autbor of Creating a Nation of Joiners: Democracy and Civil Society in Early National Massachusetts (Harvard University Press, 2008) and "American History in a Global Age," History and Theory 50 (2011): 41.70.

' Jill Lepore, Tbe Wbites of Tbeir Eyes: The Tea Pary's Revalution and the Battle oner Ameriean History (Princeton University Press 2010), 8.

${ }^{2}$ Lepore, Whites of Thrir Eyes, 15-16.

${ }^{3}$ David Waldstreicher calls this tendeacy to defer to the founding fathers "Founders chic" See his essay, Founders Chic as Culture War," Redical History Reriow 84 (2002): 185-194.

4 Lepore, Whites of Their Ejes, 124.25.

"Obama quoted in Jeff Zeleny, "Obama Slams Critics on Middle-Class Comments," New York Times, April 11, 2008, hrtp://thecaucus.blogs nytimes.com/2008/04/11/obama-slamscrics-on-middle-class-

comments $/$ sscp $^{2}=2 \mathrm{ssq}=0$ bama $\% 20 \mathrm{cling} \% 20$ to $\% 20$ guns $\% 20 \mathrm{zo}$ comments/Pscp $=2 \& s s q=0$ bama $\% 20 \mathrm{ding} \% 20$ to $\% 20$ guns $\% 202$ Kansas? How Consernatives Won the Heart of Aserica (Metropolitan Books, 2004). On these points, see also Gordon Wood's review of Lepore, "No Thanks for the Memories," Nev York Reviey of Booke, January 13, 2011. Paradoxically, Lepore may be $\mathrm{a}$ better originalist than the Tea Parriers. As many historians have suggested, the Constitution was an elite document designed, in part, to limit the populist aspirations and values of ondinary people. On this point see most recently Woody Holton, Limity pcople. On this point see most recently Woody Holton, Larn
Americans ard tbe Origins of the Constitution (Hill and Wang, 2007).

"David Thelen, "Making History and Making the United States," Journal of American Studies 32 (1998):373-397; Joyce Appleby, Lyinn Hunt, and Margaret Jacob, Telling the Trath aloant History (Norton, 1994), 15-90; and Peter Novick, Tbot Noble Drease: The "Objectivity" Question and tbe American Historical ProfesDrease: The "Objectivit" Question and lob American Historical Profes-
sion (Cambridge University Press, 1988). For a respectul discussion of popular uses and underștandings of the past, see Roy Rosenzweig and David Thelen, Tbe Presena of the Park Popular Uses of History in Aweriam Lje (Columbia University Pxess, 1998).

'On debates over history's ontological stasus, see Novick, That Noble Dream, For an argument about how recent attacks on objectivity have cleared space for older types of history see David Harlan, The Degradation of Awornican History (University of Chicago Press, 1997).

"F. R. Ankersmit, "Histurical Representation," Hirtory and Tbeof 27 (1988): 205-229; Hayden White, "Historical Emplotment and the Problem of Truth," in Saul Friedlander, ed., Proburg the Limit of Repratentation: Naziom and tbe 'Final Solution"(Harvard University Press, 1992), 37-53.
'Erik Eckholm, "Using History to Mold Ideas on the Right," Nes York Timres, May 4, 2011.

"According to the website, "Wallbuilders" goal is to exert a direct and positive influence in government, education, and the family by (1) educaring the nation concerning the Godly foundation of our country, (2) providing information to federal, state, and local officials $2 s$ they develop public policies which state, and local officials 2s they develop public policies which
reflect Biblical values; and (3) encouraging Christians to be in reflect Biblical values; and

volved in the civic arena." 27, 2011).

"Is2ac Kramnick and R. Laurence Moore, Tite Godlesr Constitusion: A Moral Deftuse of the Seexlar Stats (WW. Norton, 2005), 27, 29-44; United States Constrution, Arricle 6

12 Kramnick and Moore, Godless Conrtitution, 174.

${ }^{13}$ Kramnick and Moore, Godless Constizution, 170.

"Kramnick and Moore, Godless Conssitution, 174.

${ }^{15}$ David Barton, Separation of Clurrh and State: What the Foundern Meant (WallBuilder Press, 2007), 10

14 For Madison's Virginia experience, see most recently John A. Ragosta, Wallspring of Liverty: How Virgisia's Religioss Dissentert

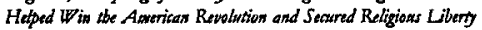
(Oxford University Press, 2010).

"Lepore, Whites of Their Eyes, 16.

" Sophia Rosenfeld, Common Sense: A Political History (Harvard University Press, 2011), 6. For an interesting discussion of why thoughtful deliberation, rather than plain common sense, upbolds democratic values, see Sandra M. Gustafson, Imagining De biberative Demarrag in abe Earby Amencen Repubtic (University of Chicago Press, 2011)

"Johann N. Neem, "A Republican Reformation: Thomas Jefferson's Civil Religion and the Separation of Church from State," in Francis D. Cogliano, ed., A Companion to Tbomas Jfferson, forthcoming from Blackwell

* Barwon, Separation of Clurrob and State, 5.

${ }^{21}$ Gordon S. Wood, "In Defense of Academic History Writing" Perppectives on History (April 2010): 19-20.

22 For some context, see Vanessa Williamson, Theda Skocpol and John Coggin. "The Tez Party and the Remaking of Repuband John Coggin, "The Tez Party and the Remaking of Republican Conservatism," Perspectives on Politios 9 (20t 1): 25-43; Alice
O'Connot, "Bringing the Market Back In: Philanthropic Aetivism and Conservative Reform," in Elisabeth $\mathrm{S}$. Clemens and Doug Guthrie, eds, Polition end Partnershipss The Role of Volvntery Associations in America's Political Past' and Present (University of Chicago Press, 2010), 121-150.

${ }^{23}$ Cerrainly that seems to be the tenor of the higher education reforms proposed by Texas Governor Riek Perry and by a recent report by the McKinsey Corporation. On the former, see Katherine Mangan, 'Texas Coalitions Spar over Scholars' Time, Research, Pay," Clirenisk of Higher Education, July 10, 2011, and Karen Tumsulty, "Texas Gov. Rick Perry Wages Assault on State's University Establishment," Waslington Post, August 3, 2011; on the latter, see Garrison Walters, "More Degrees/Dolbr-Damn the Quality?" Inside Higber Edweation, Aptil 11, 2011.

${ }^{24}$ David Hollinger, "After Cloven Tongues of Fire: Ecumenical Protestantism and the Modern American Encounter with Diversity," Jasmal of American History 98 (2011): 21-48.

${ }^{25}$ See Todd Gitlin, Tbe Intellectwals and the Fiang (Columbia University Press, 2005), 125-156.

${ }^{26}$ Lepore, Whiths of Their Eges, 162.

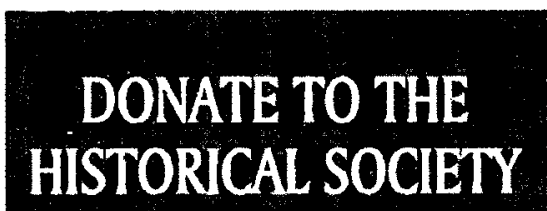

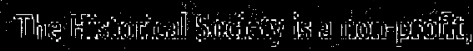
(5)

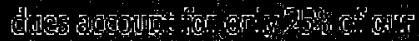

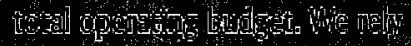

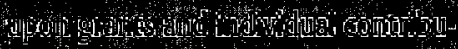

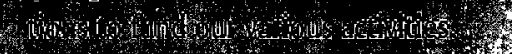

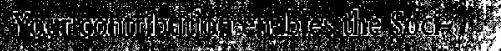
3. 1 5

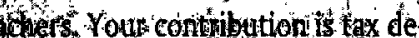
ductobut The tax identification num- ber of the

Historical Society is : 23-2857281.

Dongte $\$ 50$ or more and receive your dhoice of two books from the Historians in Conversation series. To make your contribution and receive your free books, go to:

www.bu.edu/historic/donate

Thank you for supporting the Historical Society. We cannot exist without your support.

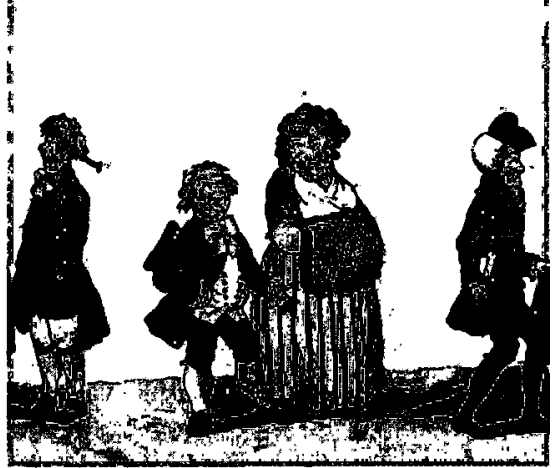

